\title{
Work - Family Conflict and Stress: Evidence from Malaysia
}

\author{
Nurnazirah Jamadin, Samsiah Mohamad, Zurwina Syarkawi, and Fauziah Noordin
}

\begin{abstract}
The objective of this study is to investigate the influence of work family conflict among the employs of a semi-government organization in East Malaysia. This study has adopted the Workplace scale that was developed by Tate, Whatley, and Clugston (1997) scale in order to measure the effect of work family conflict and the stress level among the employees. The results indicate that the employees appear to have lower level of work - family conflict and lower level of job stress. It is recommended that future research should focus on employees in other organizations both in public and private organizations. The findings of such studies would aid management of these organizations to further understand the effect of work-family conflict and stress among their employees.
\end{abstract}

Index Terms-Work-job stress, work-family conflict.

\section{INTRODUCTION}

Work and family are most important parts in human life that are not easily separated. When trying to balance between the work and family, the employees often ended with conflict and dilemma in giving priority to both career and family. The incompatible of demand between career and family seemed to create a personal pressure to the employees. More often than not, conflict tends to create pressure to the employees as they try to balance the two roles that need to be performed simultaneously.

Research on stress is widely found in the work environments in western countries but rarely found in Asia particularly in Malaysian. Understanding the factors that contribute to occupational stress is necessary for improving stress management programs in Malaysian organizations. The earlier study on sources of stress at the work place in Malaysia found that there are numerous other unmeasured variables that can contribute to stress at the work place [1]. These include individual and family factors, socio-economic and financial status, and mental and physical health factors. Therefore this study intends to investigate the influence of work family conflict among the semi government employees particularly in east Malaysia.

\section{JOB STRESS}

As time passes, the environments at the workplace become chaotic as the number of workloads of the employees increase. However, from an employer's perceptive, stress if

Manuscript received September 5, 2013; revised November 12, 2013.

The authors are with the department of Business Management, Universiti Teknologi MARA, Malaysia (e-mail: nurnazirah293@gmail.com, syavana66@yahoo.com,

fauziah716@salam.uitm.edu.my). not handled effectively with employees can result in lower productivity and have an effect on the entire organization not to mention the cost on health insurance [2]. Bunge [3] further states that "stress has a number of important elements. First, stress is not something that is out there. It is within the person. Second, is the perception of how one thinks about the situation, and the third is how the person copes with the stress." When the person's coping strategies are out of control, the person is "burned out".

Job stress can be defined as the inability to cope with the pressures in a job [4]. Job stress depends on the amount of stress a person experiences at work is likely to be a result of the interactions of a number of factors such as the type of work they are doing that is their occupation, the presence of work stressors, the amount of support they receive both at work and at home and the coping mechanism they use to deal with stress [5].

Stress has the implications for the individual as well as the organization and it can no longer be considered merely as the individual manager's problem [6]. It is now generally accepted that prolonged or intense stress can have a negative impact on an individual's mental and physical health [7], [8].

\section{WORK-FAMILY CONFLICT}

When trying to balance work and family responsibilities, many workers experience conflict between these two roles [9]. Work - family conflict has been defined as a mutual incompatibility between the demands of the work role and demand of the family role [10], [11]. Juggling work and family responsibilities is a common experience for many employees [12], [13]. Although engaging in both work and family roles can have positive effects for individuals [14], but if workers are unable to balance the responsibilities associated with both roles, the potential for conflicts between roles increases [15]-[18].

In the work setting, Rees [19] found that women encounter more stress as compared to men. The main reason is women have to balance their responsibilities towards their work and family. While Carnicer et al. [20] have found that gender is not a significant variable to explain work-family conflict.

As the consequences of work - family conflict, De Janasz [21], found that the conflict of work and family may lower job satisfaction and it may decrease the organizational commitment [22].

In order to overcome the work - family conflict, Boyar et al [23] suggested that organizations can work to reduce work family conflict by adopting family-friendly programs that help employees balance work and family demands. Specifically, their study implies that organizations should 
find ways to hold constant or reduce perceptions of work and family demand, along with other direct antecedents of work interfering with family and family interfering with work.

\section{WORK - FAMILY CONFLICT AND JOB STRESS}

Several studies in the literature have been found in examining the association between work - family conflict and job stress. The research on work - family conflict and job stress are rising because it is a growing problem [24]. Obradovic and Obradovic [25] explained that the employees experience crossover effect when the employees faced a conflict at work as well as family that ultimately affecting their spouse and family. In determining the relationship between work - family conflict and job stress, Panatik et al [26] have found that employees in Peninsular Malaysia the work - family conflict are strongly correlated with stress. Similar results for example, Sultana [27], found that working women in Peninsular Malaysia experienced higher level of job stress as compared to non-working women. Sultana [27] further explains that working women are stressful due to incapability to socialize and poor quality time with children and family. Moreover women are also found to have poor relationship with their spouses as results of demanding work schedule and unfinished work. Stress and work family conflict is a common problem faced by majority of employees especially working mothers with young children [27]. These results is supported by Kaye and Gray [24] that explained employees that tries to fulfil the increasing work role while at the same time fulfilling the family responsibilities are struggling with work family conflict and stress.

\section{PuRPose OF STUdy}

This study intends to identify the level of work - family conflict and the level of job stress among the employees in Asian context particularly in Malaysia. Although there is limited research on work - family conflict and job stress in Malaysia, the scope of previous study only cover West Malaysia rather than East Malaysia. Thus, the results of this study may enhance people understanding and enrich the body of knowledge on these particular areas.

This study aims to determine the level of work - family conflict and job stress among administrative employees of a semi-government organization. This study also aims to investigate the correlation between the work - family conflict and job stress. In addition, this study also explores the influence of gender and marital status on work - family conflict and job stress among the administrative staff employees of semi - government organization.

\section{MethodS}

\section{A. Sample}

This study was conducted in one of the semi - government organization in East Malaysia. Self- administered questionnaires were distributed to the respondents. A total of 110 completed questionnaires were found to be usable and were then analysed in this study.

\section{B. Measures and Instrument}

This study has adopted quantitative method using survey to collect data from the respondents. The Workplace Scale that was developed by Tate and Clugston [28] was used in this study in order to measure the effect of work family conflict and also the stress level among the employees. Previous studies have stated that this assessment instrument to be one of the comprehensive instruments that is suitable to use to gain understanding of employees behaviour in this modern century [28].

Empirical studies that using this instrument model have found that the internal consistency of work - family conflict variable is $\alpha=0.91$ that is above rule of thumb [29]. According to Sekaran and Bougie [29], the Cronbach's alpha that is above 0.6 is good and reliable.

\section{Data Analysis}

The data of this study were analysed using Statistical Package of Social Science (SPSS) version 17 package. To determine the reliability, each items of work - family conflict and job stress was assessed by using Cronbach's Alpha coefficient. In order to determine the level of each variable measured, the items were assessed by using mean score of each work - family conflict and also job stress variable.

This statistical technique of Independent Group T-test was used to determine if there is a relationship between the work - family conflict variables and job stress variables in this study. The purpose of this technique is to determine whether the difference between means for the two groups of gender is significant.

Apart from that, the Analysis of Variance or ANOVA statistical technique was also applied in this study to examine the differences among means for marital status groups.

In order to determine the strength of the relationship between work family conflict, job stress and some part of the demographic background of the respondents. In addition, the correlation coefficient statistical test was conducted to determine the relationship among the variables.

\section{RESULTS}

In order to explore the characteristics of the data, descriptive statistic tests were utilized. The results from the analysis show that 55 percents of the respondents that participated in this study are women that represent 55 respondents. The highest participation among the respondents comes from those that age between 31 to 44 years old that represents 46 percents. Married respondents are the higher contributor in providing a response to this study with a percentage of 74 percents which is 81 respondents.

To determine the consistency of the assessment instrument that was used in this study, reliability test was conducted. The result of the Cronbach's alpha analysis indicates that the value of alpha is 0.9. This indicates that the instrument used in this study is reliable. Cronbach's alpha for job stress shows a value of 0.92 which indicates that the instrument is highly reliable. 
The mean value of work - family conflict as perceived by the respondents is at low level $(m=2.7)$ and the level of job stress is also at a low level $(m=1.28)$. With regard to job stress, the statements on the instrument indicate that the respondents do not experienced feeling of emotionally drained to their job, burnout, frustrated, emotionally tension, loosing appetite, mentally and physically pressure about their job. All mean values of the symptoms of stress are below than 2 which indicate that the employees show a minimum level of stress in their work.

A correlation coefficient statistical test was conducted in order to determine the relationship between work - family conflict variable and job stress variable. The analysis conducted indicate that there is a significant positive correlation $(p=.510)$ between work - family conflict and job stress.

The results of Independent group T-test indicate that men and women do not demonstrate any significant difference on job stress. In addition, ANOVA with Post Hoc comparison result also indicate that marital status has no effect on work family conflict. However, with regard to the job stress, marital status have effect on job stress where those who are single appears to have significant high level of job stress ( $m=$ $1.8424)$ compared to those who are married $(m=1.1149)$.

\section{DISCUSSION}

This study examined stress and work - family conflict among semi - government employees in east Malaysia. The results indicate that the level of job stress among the semigovernment employees is at low level. The total mean value of job stress is also at low level. Based on the items of job stress symptoms that were asked to the respondents, this study have found not all respondents experienced the symptoms of job stress and only small portion of the employees may experience the job stress that occurs for a few times in a week and almost every day. Even though the level of job stress is at a low level, the results provide a signal that the management should be proactive and investigate the sources of stress as experienced by the employees before it escalates further as prevention is always better than cure. As stated by Menon and Akhilesh [6], stress has implications for the individual as well as the organization and it can no longer be considered merely as the individual manager's problem. The implications of stress either to individual or organizations have been proven by many studies.

To the individual, it will affect the employees mentally, physically, and psychologically while to the organizations it would affect directly and indirectly to the organizational performance as well as productivity. Thus, the basic causes of managerial (employees) stress need to be clearly identified and realistic strategies developed for dealing with them [30].

The level of work - family conflict among the administrative employees of semi government sector appears to be low. This means that the workloads of the employees do not really interfere with their family lives. The result on the correlations between work-family conflict and stress shows a significant positive relationship. This indicates that when the employees experience low level family conflict, the level of job stress will also be low. If the employees experience high level of role family conflict the level of job stress will also be high. The result of this study on gender and job stress support the findings of previous research for example, Nurul Izzah et al. [31] that there is no significant association between stress and gender. Nevertheless, the result in this study did not support the finding of another study [32] that indicate gender have strong association with job stress whereby both men and women experience high level of stress.

In terms of marital status, the result from this study also demonstrates that those who are single appear to have high level of job stress compared to those who are married. The results of this are consistent with previous study by Jung et al [33] who found that many factors contributed to a higher stress score among unmarried women. The reason may be because individuals who are single may hold many responsibilities as compared to married couples. Married couples may share the responsibilities and problems with their spouse while unmarried individual may have to face problems and bear responsibilities alone.

\section{CONCLUSION}

In conclusion, work - family conflict is a predictor to job stress. The administrative employees from a semi-government organization in the present study appear to experience low level of job stress and work - family conflict. The findings indicate that when the work family conflict level is low, the employees will experience low level of job stress.

It is recommended that future studies should be conducted in the areas of work-family and stress of employees in public and private organizations not only in Malaysia but also in other countries. The findings will assist us to further understand and enrich our knowledge on the work-life conflict and job stress among employees at workplace. In addition, the findings will aid the management of organizations in drafting policies in relation to work-life conflict and job stress in order to ensure a work-life balance of their most valuable assets - the employees.

\section{ACKNOWLEDGMENT}

We would like to express our deepest gratitude to our supervisor Prof. Dr. Fauziah Noordin, Director of INTEC (UiTM) for her golden advice, patience, guidance and her invaluable assistance in helping us to finish this research project. We always admire the way she review our work and how she managed to entangled the knots in our head in helping us to make this project possible.

\section{REFERENCES}

[1] A. T. Manshor, "Sources of stress at the work place", Academy of Strategic and Organizational Leadership Journal, vol. 4, no. 2, pp. 91-97, 2000.

[2] E. F. Topper, "What's new in libraries: Stress in the library workplace," New Library World, vol. 108, no. 11/12, pp. 561-564, 2007.

[3] C. Bunge and R. Rubin, (Ed.), "Stress in the library workplace," in Critical Issues in Library Personnel Management, Papers Presented at the 29th Allerton Park Institute, Graduate School of Library and Information Technology, Urbana, IL, pp. 92-102, 1987.

[4] D. W. Rees. (1997). Managerial stress- dealing with the causes, not the symptoms, Industrial and Commercial Training. [Online]. 29(2). pp. 35-40. Available: http://www.emeraldinsight.com/ 
[5] S. Johnson, C. Cooper, S. Cartwright, I. Donald, P. Taylor, and C. Millet, "Observation piece, the experience of work related stress across occupations," Journal of Managerial Psychology, vol. 20, no. 2, pp. 178-187, 2005.

[6] N. Menon and K. B. Akhilesh, "Functionally dependent stress among managers: A new perspective," Journal of Managerial Psychology, vol 9, no. 3, pp. 13-22, 1994.

[7] Health and Safety executive, "Tackling work related stress," HSE Books, London, 2001.

[8] C. L. Cooper, P. J. Dewe, and M. O. Driscoll, Stress and Work Organizations: A Review and Critique of Theory, Research and Applications, California: Sage, 2001.

[9] A. L. Day and T. Chamberlain, "Committing to your work, spouse, and children: Implications for work-family conflict," Journal of Vocational Behavior, vol. 68, no. 1, pp. 116-130, 2006.

[10] S. Parasuraman and J. H. Greenhaus, Editors, Integrating Work and Family: Challenges and Choices for a Changing World, Westport, CT: Quorum Books, 1997.

[11] L. T. Thomas and D. C. Ganster, "Impact of family-supportive work variables on work- family conflict and strain: A control perspective,' Journal of Applied Psychology, vol. 80, pp. 6-15, 1995.

[12] E. Galinsky, J. T. Bond, and D. E. Friedman, "The role of employees in addressing the needs of employed parents," Journal of Social Issues, vol. 52, no. 3, pp. 111-136, 1996.

[13] C. M. Lee and L. Duxbury, "Employed parents' support from partners, employers, and friends," The Journal of Social Psychology, vol. 138, no. 3, pp. 303-322, 1998.

[14] N. Rothbard, "Enriching or depleting? The dynamics of engagement in work and family roles," Administrative Science Quarterly, vol. 46, pp. 655-684, 2001.

[15] M. R. Frone, M. Russell, and M. L. Cooper, "Antecedents and outcomes of work-family conflict: Testing the model of the work-family interface," Journal of Applied Psychology, vol. 77, pp. 65-78, 1992.

[16] J. H. Greenhaus and N. J. Beutell, "Sources of conflict between work and family roles," Academy of Management Review, vol. 10, pp. 76-88, 1985.

[17] J. H. Greenhaus and G. N. Powell, "When work and family collide: Deciding between competing role demands," Organizational Behavior and Human Decision Processes, vol. 90, pp. 291-303, 2003.

[18] R. G. Netemeyer, J. S. Boles, and R. McMurrian, "Development and validation of work-family conflict and work-family conflict scales," Journal of Applied Psychology, vol. 81, pp. 400-410, 1996.

[19] P. Rees, "Contemporary issues in mild traumatic brain injury," Archives of Physical Medicine and Rehabilitation, vol. 84, no. 12, pp. 1885-1894, 2003.

[20] M. P. D. L. Carnicer, A. M. Sanchez, M. P. Perez, and M. J. Jimenez, "Work-family conflict in southern European country: the influence of job-related and non-related factors," Journal of Managerial Psychology, vol. 19, no. 5, pp. 466-489, 2004.

[21] S. C. De Janasz and S. J. Behson, "Cognitive capacity for processing work-family conflict: An initial examination," Career Development International, vol. 12, pp. 371-411, 2007.

[22] N. Heraty, M. Morley, and J. Cleveland, "Complexities and challenges in the work- family interface," Journal of Managerial Psychology, vol. 23, no. 3, pp. 209-214, 2008.

[23] S. L. Boyar, C. P. Maertz, D. C. Mosley, and J. C. Carr, "The impact of work/family demand on work family conflict," Journal of Managerial Psychology, vol. 23, no. 3, pp. 215-235, 2008.

[24] K. Kaye and D. Gray. (2007). The stress of balancing work and family: The impact on parent and child health and the need for workplace flexibility. Research paper. The Next Social Contract. New American Foundation. [Online]. Available: http://www.newamerica.net.

[25] J. Z. Obradovic and M. C. Obradovic, "Work related stressors of work family conflict and stress crossover on marriage quality," Unpublished research paper, Ministry of Science, Education and Sport, Republic of Croatia, Project No. 0194107, 2008.

[26] S. A. Panatik, A. Rajab, I. M. Shah, H. A. Rahman, R. M. Yusoff, and S. K. Z. Badri, "Work - family conflict, stress and Psychological Strain in Higher Education," Proceedings Paper, International Conference on Education and Management Innovation, IPEDR, IACSIT Press, Singapore, vol. 30, 2012.

[27] A. M. Sultana, "A study on stress and work family conflict among married women in their families," Advances in Natural and Applied Sciences, vol. 6, no. 8, pp. 1319-1324, 2012.

[28] U. Tate, A. Whatley, and M. Clugston, "Sources and outcomes of job tension: A three nation study," International Journal of Management, vol. 3, pp. 350-358, 1997.

[29] U. Sekaran and R. Bougie, Research Methods for Business, 5th edition, John Wiley and Sons, Chichester, 2010.

[30] W. D. Rees, "Managerial stress-dealing with the causes, not the symptoms," Industrial and Commercial Training, vol. 29, Issue 2, pp. 35-40, 1997.

[31] A. S. N. Izzah, H. Zailina, M. Saidi, and A. Haslinda, "Assessment of stress and its risk factors among primary school teachers in The Klang Valley, Malaysia," Global Journal of Health Sciences, vol. 2, no. 2, pp. 163-171, 2010.

[32] B. C. P. Kim, S. K. Murrmann, and G. Lee, "Moderating effects of gender and organizational level between role stress and job satisfaction among hotel employees," International Journal of Hospitality Management, vol. 28, pp. 612-619, 2009.

[33] K. T. Jung, S. S. Chang, K. S. Lee, Y. K. Lee, and D. B. Lee, "Stress relating factors of working women in a Bank," Korean J Occup Environ Med., vol. 11, no. 1, pp. 95-105, Mar. 1999.

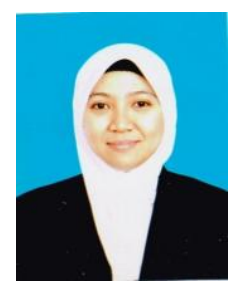

Nurnazirah Jamadin was born on $29^{\text {th }}$ March 1984 in Sarawak, Malaysia. She is currently pursuing her doctorate of Philosophy in the area of human positive psychology at Universiti Teknologi MARA, Malaysia. Ms. Nurnazirah has obtained her Master's degree in business administration in 2010 in the same university and she was awarded as one of the best Masters students in that year. Previously she obtained her Degree in Business Administration (honors) in Marketing in 2008 and Diploma in Business Studies in 2005.

She started her career as lecturer just after she graduated from her Degree in 2008. She have published chapter in Book that titled "Economy: Treading the path of post - independence" for Sarawak Government State in 2011. She is actively involved in multi - disciplinary research topics such as (1) religions, ethnics and cultures, (2) Corporate Social Responsibility and Ethics, (3) Green environment, and other areas that are related to organizational behavior and human resource management. She has presented her papers at international conferences at Indonesia, Brunei Darussalam, and also Malaysia.

Ms. Nurnazirah was actively involved in NGOs society and currently she is doing a research on corporate social responsibility and ethics with the NGOs society.

Zurwina Sharkawi was born on $29^{\text {th }}$ May 1977 in Sarawak, Malaysia. She is currently pursuing her doctor of Business Administration (DBA) in the area of marketing at UniversitiTeknologi MARA, Malaysia.Ms. Zurwina has obtained her Master's degree in business administration in 2010 in the same university. Previously she obtained her Degree in Business Administration (Honors) in Marketing in 2000 and Diploma in Banking in 1998.

She started her career as a journalist with a national newspaper for three years before work as a corporate affairs executive officer at Sarawak Timber Industry Development Corporation (STIDC), a state statutory agency. Ms. Zurwina is a member of Sarawak Astronomical Society and also actively involved in NGOs and corporate social responsibility activities 